\title{
Do Gates Negate the City? Gated Communities' Contribution to the Urbanisation of Suburbia in Pilar, Argentina
}

\author{
Sonia Roitman and Nicholas Phelps \\ [Paper first received, October 2009; in final form, November 2010]
}

\begin{abstract}
Pilar is a city located in the third ring of the Buenos Aires metropolitan region (Argentina). Over the past 30 years, the widespread development of gated residential communities has seemingly gone hand-in-hand with an urbanisation of this outer suburb signalled by the arrival of new populations, enterprise, retail and other services. The growth of the 'private city' of these gated communities therefore has important implications for the 'public city' of the wider suburban municipality. Drawing upon original research based on the opinions of key informants, this paper considers how the growth of the 'private city' has contributed to the economy of, processes of community-building and social cohesion in Pilar. In conclusion, it is suggested that gated residential communities have been a major factor in the emergence of the dual suburb that is Pilar today.
\end{abstract}

\section{Introduction}

We board the fast minibus at 8.30 am in the centre of Buenos Aires in order to make our $10 \mathrm{am}$ meeting in Pilar, some $58 \mathrm{~km}$ to the north-west. However, our 'public' transport does not ultimately go to the centre of Pilar. We make several stops to let passengers offnear a roadside office block, at the gates of a private residential development and at the entrance to a new private university - at locations just off the Panamericana highway that passes through the municipality. At a spot near a new shopping centre several kilometres short of the historical centre of Pilar, the driver advises us-the only remaining passengersthat we have to make the rest of our journey by taxi!

Sonia Roitman is in the Institute for Latin American Studies, Free University Berlin, Rüdersheimer Strasse 54-56, 14197, Berlin, Germany. E-mail: roitman@zedat.fu-berlin.de.

Nicholas Phelps is in The Bartlett School of Planning, University College London, Wates House, 22 Gordon Street, London, WC1H OQB, UK. E-mail: n.phelps@ucl.ac.uk. 
This brief story of our arriving for a research meeting in Pilar is as good as any to highlight many of the themes we wish to raise in this paper. This outer suburban municipality, known for the extent of gated residential communities, seems also to have acquired additional amenities and services. Even if these recent developments cannot be taken as evidence of the 'edge city'-style development typical in the US (Garreau, 1991), could they be taken to signal the contribution of gated communities to the urbanisation of suburbia? Except, of course, as our story implies, there is a marked disconnection between new and old elements in the development of Pilar, which instead signal the development of a dual suburb. In this paper, we concentrate on one type of private-sector actor and investorgated communities - and their impact on the improvement of the municipality. In this way, we hope to contribute to the discussion on the potential contribution of private-led development to the lives of other groups who also live in these peripheral areas.

We begin by developing a series of analytical themes regarding the contribution of gated communities to the urbanisation of suburbia-the question of their contribution to the economy, processes of community-building and social cohesion of suburban municipalities-drawing attention to some of the specificities of the Latin American context. We then discuss our case study of Pilar-an extensive, third-ring, municipality at the edge of the Buenos Aires metropolitan region (Argentina) that constitutes a good example of rapid suburban growth led by the private sector, but enabled by the public sector. Our study is based on a synthesis of academic and policy literature on the subject of gated communities (including that on Pilar itself) as well as field visits and 12 interviews with local and national government officials and civic, business and developer groups conducted on location in Buenos Aires and Pilar during April 2009. ${ }^{1}$ These were interviews with élites ${ }^{2}$ and undoubtedly our findings cannot reflect the views of the resident populations (gated community residents and non-gatedcommunity residents). Yet across these élite interviews there is enough of a critical and reflective commentary to begin to question the contribution of gated communities to the municipality in which they are located. As the site of the very first 'Country Club' in Argentina, ${ }^{3}$ Pilar is synonymous with the phenomenon of gated communities. However, we stress the disconnection that exists between these gated communities and the wider municipal economy, society and polity. In conclusion, we attempt to draw out some of the similarities and differences in growth patterns at the edge of metropolitan regions.

\section{Gated Communities and the Urbanisation of Suburban Municipalities}

It can be tempting and convenient to let analysis of a highly controversial phenomenon like gated communities take place within frameworks which we know rest on unsatisfactory theoretical dualisms. It is, for example, difficult to maintain a sharp analytical distinction between private and public space when those sites credited with the emergence of public space were originally private and where the benefits of public space may be overdrawn and those of private space overlooked (Kirby, 2008). ${ }^{4}$ The apparent exclusionary nature of gated communities as private governments can be made to stand in stark contrast to ideals of public space, the public realm, and municipal government. In theoretical terms it is possible to interpret gated communities as clubs that straddle the public-private divide (Webster, 2002). After all, the technical means of exclusion most commonly associated with gated communities-the walls, fences and security devices - are only one among several other means of social exclusion (legal, financial or cultural). In theory, then, gated 
communities must be regarded as one element in what could be considered as a trend towards fragmentation of the urban fabric, social segregation and privatisation.

Gated communities are enclaves that are "opposed to the city, which is represented as a deteriorated world" (Caldeira, 2000, p. 264). Nevertheless, the large and growing body of empirical studies of gated communities makes it clear that-for all their attempts at containment-these private spaces do have wider economic, social and political effects. ${ }^{5}$ This raises an important question of whether these communities do indeed contribute to the urbanisation of suburbia and a roundingout of settlements regarded as suburban and their impacts on the development of prosperous, open and socially cohesive communities

Rather than try to pigeonhole this new social and political entity, it is more important to examine it from the standpoint of its relative legitimacy and possible effects on the meaning of citizenship (McKenzie, 1994, p. 144).

\subsection{The Economic Implications of Gated Communities}

Potentially, gated communities have positive economic consequences for the municipalities in which they are embedded as they can improve the local economy (Sabatini and Salcedo, 2005), create low-skilled jobs (Svampa, 2001) and increase tax revenues (Le Goix, 2005). Yet, "The segregation that gated communities represent is intentionally economic" (Blakely and Snyder, 1997, p. 153). Indeed, Blakely and Snyder (1997) suggest that gated communities are not very good at producing public goods, while the underuse of common facilities is suggestive of the value of such residences not as clubs, but purely as signifiers of social status (Caldeira, 2000). ${ }^{6}$ These considerations should alert us to the probably modest economic 'spillovers' created by the emergence of gated communities in any municipal context.
First, gated communities may themselves be important sources of employment. Their development doubtless provides a range of temporary job opportunities related to construction activities, while after completion a range of further job opportunities will exist primarily in the form of service occupations such as cleaning, gardening, maintenance and security. Additionally, they create a new demand for certain services in the local area such as food places, shopping and entertaining areas and education and health amenities.

Secondly, what of the overall impact of gated communities on the fiscal position of suburban municipalities? There is a case for believing that the impact of gated communities on the fiscal position of local government is on balance likely to be negative since

In many cities and towns, the wealthy have in effect withdrawn their dollars from the support for public spaces and institutions (Reich; quoted in McKenzie, 1994, p. 23).

However, if the economic rationale represented by gated communities is one of the preservation of property values, this has ambiguous implications since it can be argued that gated communities make positive contributions to the local tax-base (Le Goix, 2005). Here, the impacts of gated communities reverberate differently at different geographical scales. As suggested by Le Goix

local governments usually favour the development of this form of land use to pay for the cost of urban sprawl, while indeed producing social diseconomies for the whole metropolitan area (Le Goix, 2005, p. 323).

These social diseconomies refer to issues of social exclusion within and between municipalities, disparities in tax and social expenditure impacts between municipalities and political secession from representative democracy and government at the municipal level. 
Thirdly, in most planning systems there is the possibility for local governments to extract some measure of 'planning gain' in return for granting planning permission for the development of gated communities. Planning gain can represent an important and highly versatile means of ensuring that these private developments contribute to the social cohesion and urbanity of suburban municipalities, through the likes of additional services, amenities and infrastructure open to all. The sophistication of local government in bargaining for such planning gain varies enormously and in some settings is sufficiently inconsistent and non-transparent in its organisation to be mired in issues of corruption. Nevertheless, the leveraging of economic benefits in this way by municipalities reveals much about the contribution of gated communities to efforts at community-building, as we shall discuss.

\subsection{Gated Communities and Community-building}

Gated communities are argued to sharpen the focus on important issues of "private versus public rights, and responsibilities and the practice of community" (Blakely and Snyder, 1997, p. vii). The problem is that the collective interests, or club good properties of the gated communities, significantly shift the balance that has traditionally held sway in community-building. In gated communities

a resident's responsibilities to the 'community' can be satisfied by meeting one's economic obligations ... But cities, states and nations have vast networks of public and private threads that tie citizens together and make them interdependent. We are linked ... in ways that encourage or compel us to be responsible to, and for, each other. These responsibilities extend far beyond maintaining property values and conformity (McKenzie, 194, pp. 148-149).

We might add that these responsibilities also extend beyond the territorial boundaries of any particular gated community. The common interests or values and the tightly defined legal basis of these communities belie what Doreen Massey (1994) would regard as a relational sense of place and an associated ethical responsibility whereby our attachment to territorially bounded community need not to be at the expense of responsibilities of care to other communities near and far.

We can go further with McKenzie to note how

This form of private government is strikingly different from that of cities. In a variety of ways, these private governments are illiberal and undemocratic. Most significantly, boards of governors operate outside constitutional restrictions because the law views them as business entities rather than governments (McKenzie, 1994, p. 21).

However, they themselves are no respecters of their own boundaries as private corporate entities because, by engaging in political behaviour and wielding political power in the public governmental sphere, they have in many respects seceded from shaping the growth and activities of local civic institutions. Thus, the existence of a private government (a group of residents who are in charge of the management of the everyday life of gated communities and have the power to decide on regulations and fines for those who do not follow these regulations) and of a code of conduct concerning behaviour and house construction shows the extent to which gated communities imply a disengagement from public governments and public regulations.

If gated communities represent privatisation, it is a more fundamental form than we usually associate with the word since, in advanced economies such as that of the US, conscious collective decisions, in the form of public policy and laws at state or federal level, have been made to privatise by way of gated communities. This form of privatisation has occurred in a context of public inaction to the extent that, within political discourse 
surrounding gated communities, public government itself is seen as a variable (McKenzie, 1994). And yet, as Pírez notes

each private development is seen as a 'city', which hides the fact that its existence is only possible within the city that provides it with the means of existence (Pírez, 2002, p.155). ${ }^{7}$

In other national contexts, as we will see in the case of Pilar, the form of privatisation represented by gated communities has been led by the private sector, but has been actively enabled by laws and urban planning.

\subsection{Gated Communities and Local Social Cohesion}

A third set of wider impacts of gated communities can be considered in terms of social interaction and segregation. Indeed, most literature discussing gated communities and segregation links them with social segregation. ${ }^{8}$ Several authors highlight the broader significance of gated communities to societies and local government when insisting that the phenomenon of gated communities is cultural (Webster, 2002). Blakely and Snyder, for example, argue that

Gated communities are not merely another form of residential settlement. They are part of a deeper social transformation (Blakely and Snyder, 1997, p. vii).

In this respect, it is clear that gated communities signal a particular cultural and social transformation. Gated communities embody a

culture that links ownership of private property with freedom, individuality, and autonomy rather than with responsibility to the surrounding community (McKenzie, 1994, p. 25).

Hence they can be regarded as further evidence of the mutation or refinement of the suburban ideology (Fishman, 1987; Teaford, 1997). However, their contribution to the social complexion and ideology of suburbia is somewhat ambiguous and potentially rather different in different national settings.

Blakely and Snyder argue that

Gated communities have created a new housing option for some of us, but they have also created a new societal dilemma for all of us. The purpose of gates and walls is to limit social contact, and reduced social contact may weaken the ties that form the social contract (Blakely and Snyder, 1997, p. 137).

One irony here is that

The withdrawal from the city's public life and from the use of its public spaces is seen as a privilege only by those whose participation in it is taken for granted and who can dream of creating better and more exclusive universes (Caldeira, 2000, p. 289).

The urban fragmentation with which they are associated is not necessarily or straightforwardly associated with social segregation. The impacts of gated communities on social segregation at the intramunicipality and intermunicipality scales seem to be different in different national contexts. On the one hand, gated communities appear likely not to increase intramunicipality social disparities, but to reinforce the relatively homogeneous White middle-class complexion of many US suburbs and hence levels of social segregation at the intermunicipality scale. On the other hand, gated communities have increased social segregation at the intramunicipal scale in Latin American suburbs, with poor and rich neighbourhoods close to each other, but divided by walls (Roitman, 2008). The novelty in the Latin American case is that, with the development of gated communities, affluence has spread to new areas, especially the periphery. 


\section{Gated Communities and the Latin American City}

So far, we have spoken of some of the generalities of the nature and wider impacts of gated communities. However, it is as well to remember that the growth of gated communities and their impacts on patterns of urbanisation and suburbanisation are context specific. In this respect, while we can discuss the generalities referring to Latin America as a whole, there are important historical, social, political and economic differences that also need to be considered. Borsdorf et al. have quoted Vidal-Koppmann and Dietrich's (2005) description of Buenos Aires in translation, suggesting that it could apply to the Latin American city in general

urban fragments surrounded by illegal marginal settlements, rubbish dumps to open sky next to small and medium units of the traditional urban plot, parks and industrial areas very close to luxury residential quarters, and freeways having been constructed over local earth roads without any maintenance (Vidal-Koppmann and Dietrich; quoted in: Borsdorf et al., 2007, p. 370; their translation).

Such descriptions are reminiscent of depictions of the post-modern urban fabric of Los Angeles (Dear and Flusty, 1998), but it would be wrong to regard these patterns of fragmentation as equivalents.

To begin with, the first and major general contrast to be drawn between the US and Latin America is with regard to the socioeconomic complexion of the suburbs. Notwithstanding the historical and contemporary diversity of US suburbs which has been recognised, the general affluence of US suburbs contrasts starkly with those in Latin America which are populated mainly by lower social classes. This pattern in the metropolitan periphery of Latin America has shifted somewhat in the past 20 years as middle- and upper-class populations have moved to the suburbs. This has created a situation in which poor and rich families live in close proximity (Roitman, 2008; Sabatini and Cáceres, 2004).

A recent survey of studies of urban sprawl in Latin America and Europe situated gated communities as part of successive processes of suburbanisation, peri-urbanisation and postsuburbanisation (Borsdorf and Hidalgo, 2008). However, the connection of gated communities to post-suburbanisation - the urbanisation of suburbia-in Latin America can usefully be specified further in terms of features that set Latin American municipalities apart from their US counterparts. First, in a fashion not dissimilar to that in the US, Latin American metropolitan peripheries have been concerned to attract gated communities. In order

to deal with their lagging economy and bring new investment, suburban municipalities relied on their planning autonomy to foster the development of gated communities (Libertun de Duren, 2007, p. 607).

These developments have superficial generic similarities with those in the US, but are probably best thought of as representing a 'temporal disparity' - a difference in the phasing of similar patterns and processes of urbanisation in different countries_-which makes direct comparison problematic (Phelps et al., 2006). Instead, following Dick and Rimmer's discussion of East Asian city-regions (Dick and Rimmer, 1998), it may be best to depict Latin American cities as passing through a number of phases of divergence from and convergence on US patterns of urbanisation. Interestingly, one such element of convergence taking place simultaneously against other divergent developments is the emergence of what Pírez (2002, p. 157) terms “a 'one-dimensional city': use value becomes subordinated to exchange value" in the development of land. This is reminiscent of the growth machine logic (Molotch, 1976) that drove the post-war mass suburbanisation in the US. ${ }^{9}$ 
Secondly, one specificity of the Latin American, and indeed transition economies in comparison with developed economies, comes in the contrast in the resources and technical capacities of municipal governments and the newly created private governments of gated communities. Historically, the public sector was heavily involved in the suburbanisation process in Latin America through the construction of social housing developments. The state was intimately involved in producing the particular socioeconomic complexion of these areas and, indeed, in establishing some of the on-going burdens of suburban municipalities in trying to rectify poor levels of infrastructure and services. More recently, the suburbanisation process has been led by private planning activities associated with gated communities (Pírez, 2002), not least since the human resources devoted to forward planning, development control and enforcement in municipalities remain limited, and certainly behind those in most developed countries. The situation is not improved by the lack of regulatory framework on which municipalities can draw. According to Pírez (2002, p. 155), "the metropolitan area becomes a space for operations seeking, largely or almost exclusively, private economic gain" because there are no clear or consistent regulations on land use.

The relationship between gated communities superimposed upon outer suburban areas and the possibilities for existing grass-roots political movements to shape a viable politics centred on issues of collective consumption and the 'retrofit' of amenities and infrastructure is unclear. There is some evidence of grass-roots political movements having produced legacies for a municipal politics of collective consumption in Europe (Phelps et al., 2006). Caldeira (2000), in discussion of gated communities in Brazil, seems to imply that their growth has coincided with a decline in possibilities for such grass-roots activism associated with auto-construction of housing.
Moreover, the privatisation embodied in these gated communities has coincided with what Pírez (2002) describes as a triple fragmentation (institutional, technical and territorial) in the management of public services in the Latin American context. All of these factors present significant challenges to the task of community-building in the public city.

Thirdly, in relation to Santiago de Chile, Sabatini and Cáceres argue that the pattern of large-area segregation in Latin America is changing towards a process of segregation in smaller areas, but more intensively

The multiplication of gated communities that is taking place in Chilean cities is equivalent to a diminishing of residential segregation in large areas and, simultaneously, to an intensification of segregation in smaller areas. This change in the segregation scale takes place when gated communities are built in the low-income periphery (Sabatini and Cáceres, 2004, p. 11; our translation).

However, it is relevant to emphasise that Latin American cities have been characterised by social segregation since their development by the Spanish and Portuguese conquerors, yet what it is new now is the appearance of gated communities as symbols of this process of segregation (Roitman and Giglio, 2010).

Gated communities in Latin America play an important part in the reshaping of the suburbs, as Caldeira describes

Superimposed on the center-periphery pattern, the recent transformations are generating spaces in which different social groups are again closer to one another but are separated by walls and technologies of security and they tend not to circulate or interact in common areas (Caldeira 2000, p. 213).

Indeed, it may be true to say that the presence of gated communities in suburban Latin America is both more conspicuous and more profound than in the US, because of their 
superimposition upon some of the poorest populations within metropolitan areas. Thuillier notes that

upper class enclaves, requiring huge areas of land, spring up at the fringes of the metropolis, which in Buenos Aires do not consist of 'edge cities' but of slums concentrating the poorest and more recent immigrants in town, coming from the most underdeveloped provinces of the country. Therefore a striking contrast appears at the outskirts of the Metropolitan Area (Thuillier, 2005, pp. 255-256).

Hence" the two extremes of the social spectrum in Argentina co-exist through the settlement of gated communities amongst this desolate suburban landscape" (Thuillier, 2005, p. 263).

In sum, taking these specificities into account, there are, as Webster (2002) notes, different challenges posed by the growth of gated communities in different settings. Issues of secession are perhaps most pressing in the US, whereas it is the balancing of municipal revenues with the costs of gated communities that is apparent in Europe. However

In Asia, South America, and Africa, the issue is one of how to let the market provide the professional middle classes with the urban services they aspire to without critically fragmenting highly unequal cities (Webster, 2002, p. 400).

Borsdorf et al. (2007, p. 377) go further to argue that "Exclusion itself may be regarded as the central structuring force" emerging in Latin American cities in some contrast to the US and Europe, in addition to status and social distinction (Caldeira, 2000; Roitman, 2008). The next section explores the specificities of Pilar, the municipality that has the highest number of gated communities in Argentina.

\section{Pilar: from Country Club to Edge City?}

Pilar lies 58 kilometres to the north-west of the centre of Buenos Aires in the third ring of municipalities within the metropolitan region of Buenos Aires (Figure 1). It is vast by European municipal standards, covering some 383 square kilometres. ${ }^{10}$ The predominant activity in the municipality is still agriculture, with 58 per cent of its land used for this (Barsky and Vio, 2007). However, it is one of the third-ring municipalities with a very high population growth rate: 55 per cent in the period 1960-70, 77 per cent in 1970-80, 54 per cent in 1980-91 and 78 per cent in 1991-2001 (Pírez, 2002; and INDEC, n.d.). In 2001, it had a population of 232463 that was expected to grow to 274000 by 2007 (INDEC, n.d.).

The city and district of Pilar have existed since the 19th century, centred historically around the main square-the Plaza 12 de Octubre. Following the pattern of Latin American cities, this historical core has been overlain by self-constructed buildings until recently. Libertun de Duren (2007) reports that in the 1980s a third of houses in the municipality were of sub-standard condition, with two-thirds of houses lacking piped water. By 2006, 25 per cent of the population still had unmet basic needs in Pilar but yet co-existed with over 100 gated communities (Vidal-Koppmann, 2007). As the largest municipal concentration of gated communities in Argentina, now sitting alongside both the existing middle- and lower-class population and the new poor neighbourhoods, it provides an extreme exemplification of the patterns of what has come to be regarded as something of a distinct phase of urbanisation of the Latin American city, albeit a phase that has its roots in earlier times.

Different definitions of gated communities make it extremely problematic to provide accurate comparable time-series figures on the numbers of such developments (Roitman, 2008). Here, we use a variety of sources to provide some very general impressions of the growth of gated communities in Pilar (Figure 2), although individual figures cannot be regarded as comparable. The number 


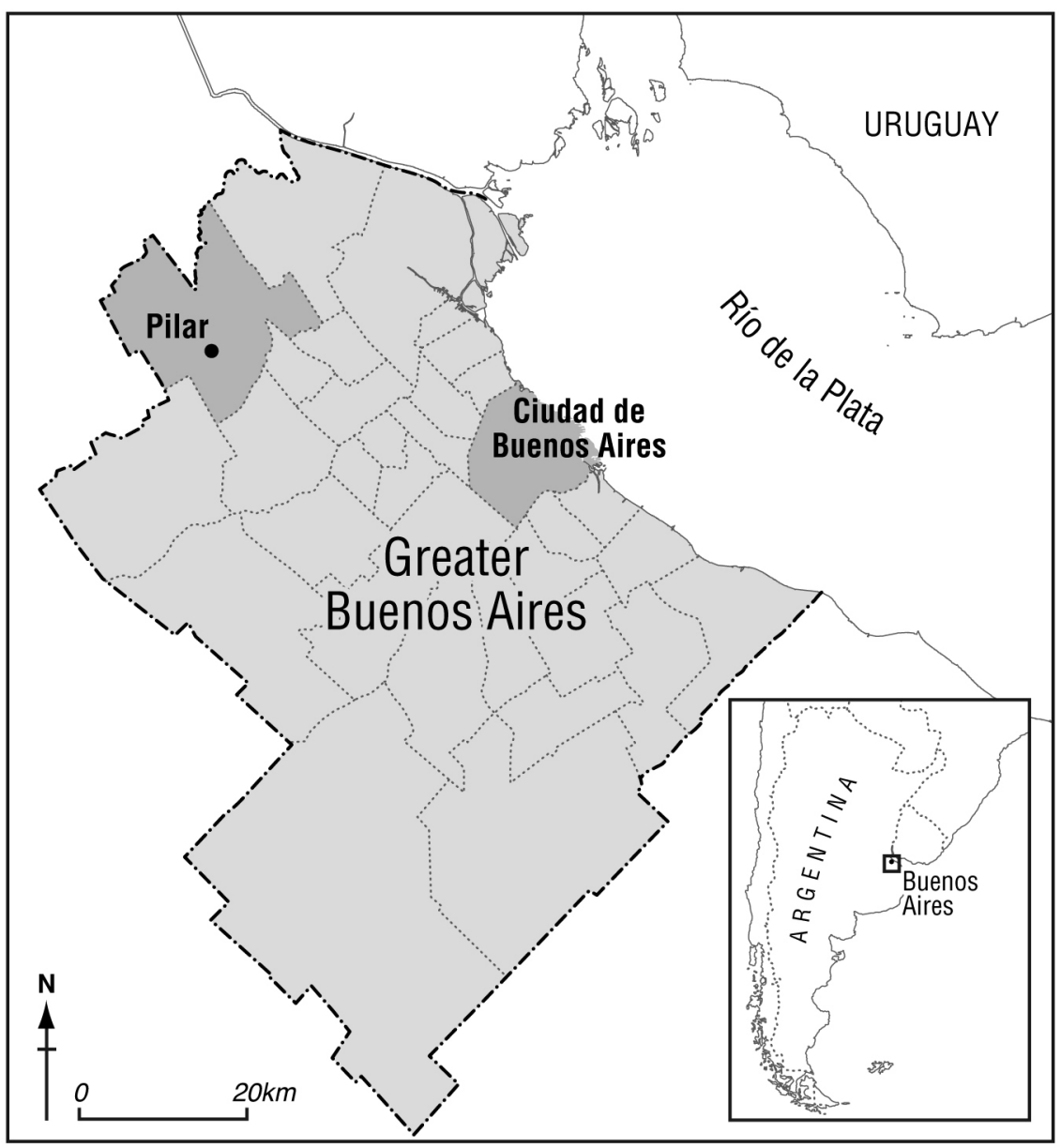

Figure 1. Location of Pilar in the metropolitan area of Buenos Aires.

of gated communities rose from 20 in 1980s, to 30 in 1991, to 115 in 2001 (Libertun de Duren, 2007). The most recent occasional publication, Guía de Countries, Barrios Privados $y$ Chacras, put the figure at 98 in 2005 (Publicountry, 2005), while Vidal-Koppmann (2007) mentioned there were 117 in 2006, occupying 54 square kilometres (Barsky and Vio, 2007). Such large numbers also translate into a significant part of the land area of the municipality being given over to gated communities, with 58 per cent of land taken up by agricultural activities, 17 per cent by residential development in gated communities, 12 per cent by residential development in 'open neighbourhoods', 10 per cent by empty land and 3 per cent by industrial uses (Barsky and Vio, 2007).

The history of gated communities in Pilar began with the creation of the Tortugas Country Club in 1930 as part of the Las Tortugas Polo Club (Verdecchia, 1995; Svampa, 2001). These 'country clubs'11 were related to the sports activities of élite groups who lived in Buenos Aires, with houses used only during weekends. Later in the 1970s, this 


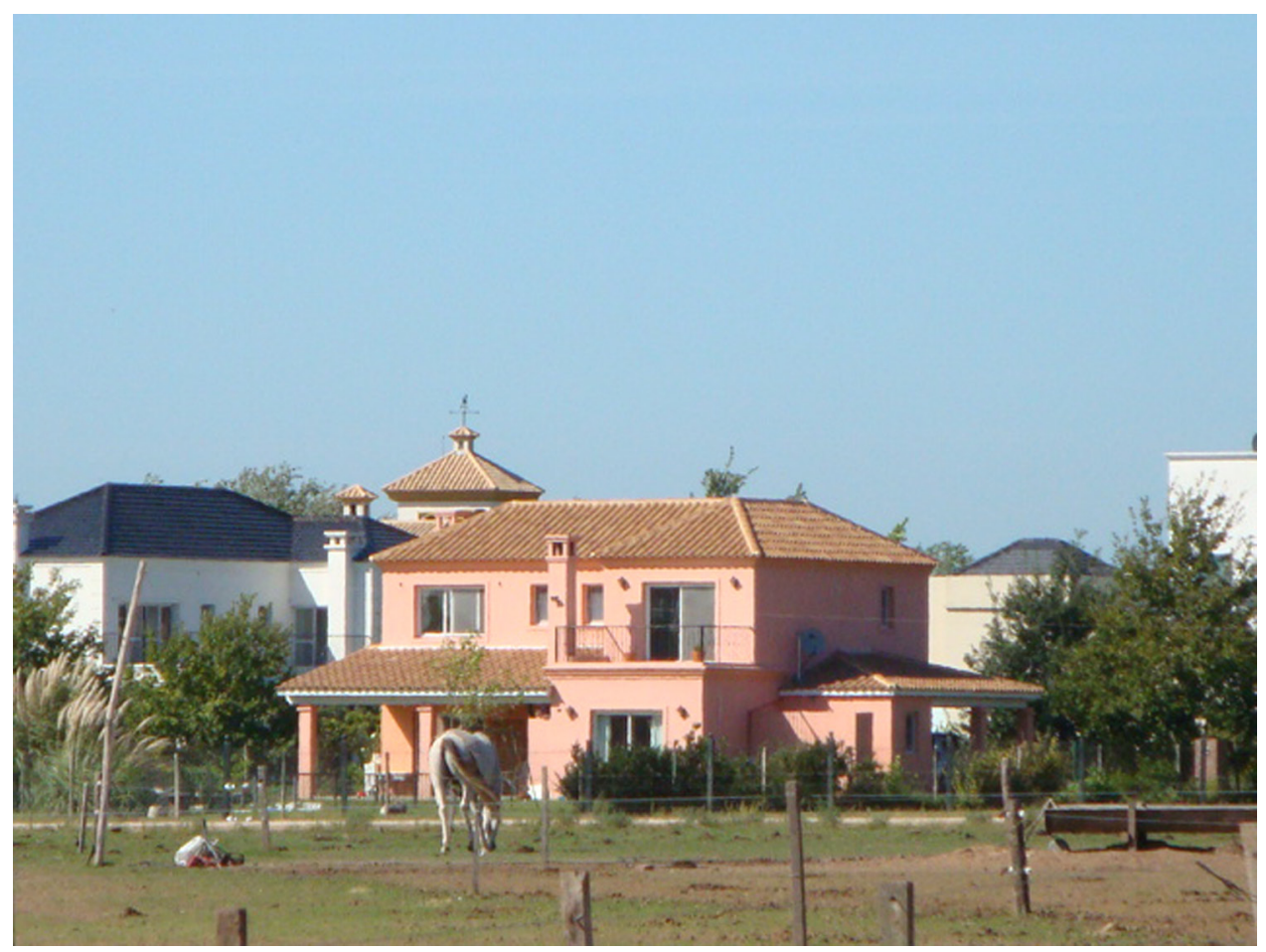

Figure 2. Houses in Estancias del Pilar.

type of residential development expanded as people living in the city wanted to have larger weekend houses, with important sport infrastructure and within a green environment. From the late 1990s onwards, they became mainly used as permanent residences as families could not longer afford having two houses, one in Pilar and one in Buenos Aires city. Thus the original growth of Pilar as a location for 'country clubs' was limited, exclusive and based on the environmental quality of the area as one interviewee described

It had been chosen by the people, because of its landscape beauty. All 'country-clubs', which were already old, were in Pilar and you had a very high-class group of residents. Nobody did that, it was done by nature or the charm of the place. Some old residents told me that Pilar had always been used as a high place for people with asthma or breathing problems. 'Country-clubs' were already there ... This was the beginning of Pilar (president, national construction company, main developer of gated communities in Pilar, 20 April 2009).

The major growth of gated communities in the metropolitan periphery took place from the 1990s onwards. Pilar attracted many of these gated communities and with them a major increase in population. However, growth in this phase was based not on the environmental quality that had attracted previous gated community developments, but on a major latent demand for this style of living, coupled with increased accessibility from the periphery to Buenos Aires city centre as a result of the improvement of the Panamericana highway. ${ }^{12}$ Thus, according to one interviewee 
I think Pilar grew not because it promoted growth but because it was 'invaded' by a need that was created in another place. For instance, Capital Federal: people who wanted to go outside Capital and moved to a place more in contact with nature, healthier for their children. This was combined with the possibility that the 'new' Panamericana brought. [Before] it was unthinkable that you would live 60 kilometres away from Capital and you would commute everyday. The highway made that possible (representative, Chamber of Business, Pilar Industrial Park, 7 April 2009).

In general, the recent growth of these gated communities was linked to the search for an explicitly suburban way of life, but also with a degree of social differentiation. Barrios privados (also called barrios cerrados_closed neighbourhoods) represented a more affordable version of the 'country clubs'. This type of gated community has developed since the 1990s. Sport infrastructure is not as significant as in 'country clubs', but they also usually have tennis courts, a swimming pool and maybe a football pitch, in addition to a club-house for social events. Security is the most valued service. They are mainly used for permanent settlement. The newest type of gated communities is called 'condominium' ${ }^{13}$. It was developed after 2001 as a consequence of the economic and institutional crisis in Argentina to provide a more affordable housing option. They are two- or three-storeyed buildings with security and usually do not have a significant sport infrastructure for common use. They occupy smaller areas than the other types and are likely to be, along with barrios privados, the most-constructed type in Pilar over the past nine years.

According to some of the interviewees, the 'collapse' ${ }^{14}$ of the Panamericana highway due to increased traffic flows heralds the end of the 'boom' in gated community development in Pilar. However, the figures for land use reported earlier indicate that the vast majority of land in Pilar is under agricultural use and presumably open to conversion to residential use in the future. As one interviewee described

You have the feeling that Pilar exploded and all has been developed but if you see it from the air, you see that in fact 70 per cent of the land is agriculture land. There is still a lot, lot, lot to be developed (CBRE consultant, 20 April 2009).

Moreover, only a modest proportion of many of the largest gated community developments have to date been built-out. The developer of one large gated community indicated that as little as 30 per cent of the planned development had to date been completed (developer of a mega-project in Pilar, 15 April 2009).

\section{The Economic Impacts of Gated Communities in Pilar}

The vast majority of foreign direct investment into Pilar from the 1990s onward has been associated with residential real estate. Yet other activities such as industry, private and public services and commercial activities have grown to a lesser extent (Director of Planning, Municipality of Pilar, 7 April 2009). At first glance the growth of gated communities and population in Pilar appear to have been accompanied by other developments that might be considered evidence of the urbanisation of the suburb. These include an industrial park, office blocks, hotels, cinemas, shopping centres, university campuses and a new private park for technology, along the Panamericana highway. Doubtless there are some causal connections between the growth of gated communities and these other elements in their spatial arrangement, but the fuller sense of how they knit together the community remains unclear.

Although Pilar has a number of industrial areas, its main industrial park is by far the most important employment and economic activity zone in the municipality. Covering 920 hectares, it is home to around 180 
companies and 12000 staff (representative, Chamber of Business, Pilar Industrial Park, 7 April 2009). It contributes 89 per cent of the economic structure of Pilar in comparison with 6 per cent for commerce and 5 per cent for services (Barsky and Vio, 2007). It was located in Pilar because a private developer saw the potential of the area, and was supported by legislation that encouraged the creation of industrial parks 50 kilometres or more away from Buenos Aires. It was actually developed in 1978 prior to the recent growth of gated communities, but does provide job opportunities to the same new migrant populations as the existing gated communities. Industries located in this park get tax exemptions if they hire local population. In addition to this, the increasing capital and knowledge intensity of some of the enterprises in the park now also offers important employment opportunities to skilled and professional workers from the gated communities.

Pilar has become home to several office developments and new Sheraton and Howard Johnson Hotels along the Panamericana highway. They include the offices of Grupo Farallón-one of the major gated community developers active in Pilar and elsewhere in the Buenos Aires metropolitan region. However, taken in the round, these developments are modest in size and certainly are not regarded as a separate office sub-market within the metropolitan sphere by commercial property brokers because big companies want to stay in Buenos Aires and not in the periphery (consultant, CBRE, 20 April 2009). Pilar also has a major new out-of-town shopping and entertainment centre located at 'Kilómetro 50', which includes two shopping centres, a hypermarket and a multicinema complex (Figure 3). Another shopping centre

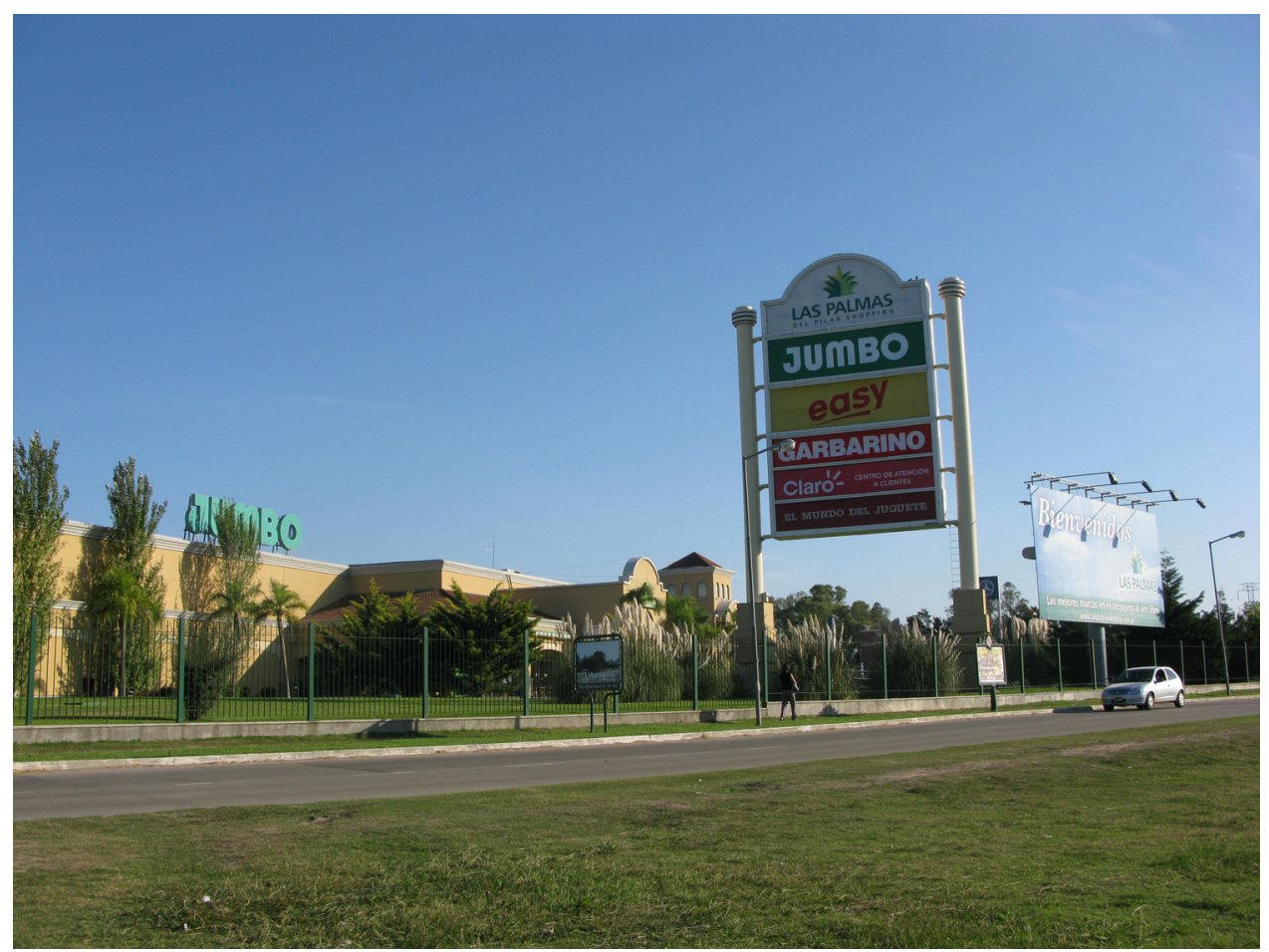

Figure 3. Shopping centre in 'Kilometro 50', Pilar. 
is being built at 'Kilómetro 34'. Hence, in formal employment terms, it would be very misleading to regard somewhere like Pilar as an edge city in terms of the scale of tertiary activity located there.

The arrival of this new affluent population in Pilar has created a new demand for bilingual private schools in the area. However, this was a mutually reinforcing process because the new population demanded new schools and the new schools attracted more people

there are now about 90 [both primary and secondary] bilingual schools in Pilar. I think it is the only municipality with so many bilingual schools (real estate agent, Haydée Burgueño and Asoc., 15 April 2009).

There are also two private universities, a state university and a private university hospital located in Pilar

Pilar is the municipality where there is more relocalisation of services from Buenos Aires: the Universidad del Salvador, the Universidad Austral and the Austral Hospital. You see how it is a place chosen for some services ... These universities are still here in the centre [of Buenos Aires], but they are now also located there [in Pilar] to serve those high-income groups (Advisor, Secretary of Municipalities, National Government, 8 April 2009).

In addition, encouraging the universityindustry relationship, the Universidad Austral has recently developed the first stage of the Austral Park, for companies working on technology and scientific development (Ciccolella and Vecslir, 2010).

However, the physical separation of these various new elements contributes to a sense of fragmentation in the municipal space. This is nowhere more apparent than in the case of the major shopping centre at Kilómetro 50. The story of how the location of this major service centre occurred is revealing
In 1980 or 1982 , I went to a one-day seminar ... I listened to all the meetings the whole day. All NyCs [nacidos y criados] $]^{15}$ were there of course. The discussion was that Jumbo, and Disco [supermarkets] wanted to go to Pilar ... The NyCs were saying: 'we won't accept that these people [supermarkets] come here'. So at the end of the meeting, the mayor said to the NyCs: 'okay, I accept what you say, but what should I say to the people that want to come here to put a supermarket? Don't you think that this is ridiculous?' So the NyCs said: 'Okay, we will make it possible for them to locate in the area between [Route] 234 and Panamericana [which later became known as 'Kilómetro 50']'. This was a low-lying area that was flooded every time it rained. So all [NyCs] were laughing saying 'look how we bug them'. So I said to them: 'remember that you have just founded the new commercial centre of Pilar'. All of them laughed and said: 'they will be in canoes' and of course today they are desperate because 'Kilómetro 50' was born because of their mistake (president, national construction company, main developer of gated communities in Pilar, 20 April 2009).

Here, it appears that different municipal stances have resulted in different patterns of incorporating gated communities into their suburban fabrics. Pilar's myriad scattered communities compare less favourably with tightly clustered development in San Isidro and a sector of gated communities that has the potential to be integrated into public infrastructure networks such as the road system in Tigre (Libertun de Duren, 2007). ${ }^{16}$

Still, it might be objected that, on the face of it, the extent of development activitygated residential complexes, offices and hotel developments and shopping centres_-ought to confer financial benefits on the municipality and an improvement in its fiscal capacity

I think there is no debate about the capacity of municipal governments to generate tax revenues. Sometimes they think that because those neighbourhoods [gated communities] 
build their own infrastructure, then they shouldn't pay taxes that would benefit the whole community. But the reality is that those neighbourhoods use public space, fragment urban fabric, don't allow other people to go through some places using them as shortcuts, and make security conditions of the rest worse. So there are many reasons why there should be different criteria for taxation and they should pay more (Secretary of Municipalities, National Government, 8 April 2009).

Yet studies indicate that the tax position of Pilar has not improved noticeably with the vast growth of gated communities and any associated developments (Goytia, 2005). Some explanation for this comes from the fact that current provincial law allows for between 10 and 15 per cent of real estate tax to go to municipalities. As a result, local government officials do not see this as a major source of income and may be little inclined to maximise contributions.

Instead, it is the consumption patterns of new affluent residents and the employment opportunities that gated communities offer that are seen by local government officials as the major economic benefits locally (Libertun de Duren, 2007). One interviewee from the national representative organisation of gated communities in Argentina suggested that

each house provides directly 2.5 new jobs, in addition to all services that could be related to that, like supermarket, newspaper delivery person, cinema, etc. (manager, Argentinean Association of Gated Communities, 8 April 2009).

Thus, Libertun de Duren (2007; citing Thuillier, 2001) notes how officials in Pilar believed gated communities offered employment for around 30000 people. These jobs come at a price in that the costs of providing infrastructure and services to these new, often informal, settlements remain the responsibility of the municipality. As one interviewee explained

there has been a huge growth of the population and then there is not enough infrastructure and services and the government has to attend to a huge demand for all sorts of services. I am always personally impressed by the variety of problems they have to attend to: the industrial park has one [particular sort of] problem[s], but also there is the person who is jobless, or needs a school for his/her children, or a free pass for public transport. Then you have the 'country' [country club], which has a different socioeconomic level and has different needs and also problems but is demanding security in the access road to the 'country' [country club] (representative, Chamber of Business, Pilar Industrial Park, 7 April 2009).

This quotation neatly captures some of the divergent needs and expectations in the dual suburb of Pilar which we consider further in the next section.

Even in the more mature political and municipal institutional context of developed nations such as the US and the UK, bargaining with investors for planning gain-although now accepted as legitimate-is a comparatively recent phenomenon which, as recently as 30 years ago, was limited in its scale and scope and unsophisticated in approach. Not surprisingly in the context of relatively small and poorly resourced municipal bureaucracies in Argentina, bargaining for planning gain has been limited and mired in perceptions of corruption. As one local official in Pilar, speaking to a national newspaper, indicated

Of course we did not ask them [the investors] for a bribe, but we did ask them to collaborate with the people ... Pilar del Este [a new gated community] is paving 1.5 kilometres in a street, which used to be in terrible shape. That is the mother idea: If the municipality cannot, let the private sector give us a hand (quoted in Libertun de Duren, 2007, p. 620). 


\section{Gated Communities and Community-Building in Pilar}

The sorts of discontinuities in the extent, character and causes of the gated community phenomenon and associated population changes in Pilar, already noted, have taken place in a context in which there is no national law on gated communities in Argentina. Some projects have been created under the national law 13.512 of Horizontal Property of 1948 . This law was originally created to regulate high-rise buildings specifying the difference of individual property from common property. It states that owners of flats are exclusive owners of their flats and co-owners of the land and common spaces within the building. When this law is applied to 'country-clubs', the streets and common areas are treated as condominium property. This law also regulates maintenance fees. Due to the growth of gated communities in Buenos Aires, other legal instruments were created later. The provincial decree $8912 / 77$ was written regulating land use in the Province of Buenos Aires in 1977. It was the first legal instrument that considered the legal character of gated communities. It establishes the minimum plot size, maximum number of houses in each development and gives guidelines for the provision of services and infrastructure. It also states that municipalities are responsible for regulating land use. By the end of the 1990s, this province had passed more legislation (decrees and by-laws) on gated communities to overcome the legal void at the national level. However, many projects are still considered under National Law 13.512. During the 1990s, many municipalities also passed by-laws to legislate on this topic. Pilar was one of the pioneers in a sense with the bylaws 142/94, 148/94, 70/95 and later 2840/05.

Within this legislative context, municipalities are left to create their own regulatory planning and strategic stances towards gated community developments which can vary quite markedly within the Buenos Aires metropolitan region. As already stated, Pilar is one of the few municipalities with by-laws regulating gated communities, although there is some suggestion that it has nevertheless lacked a clear and consistent approach to dealing with gated community developments in comparison with other municipalities (Libertun de Duren, 2007). In particular, there has been no long-term strategy to deal with or leverage maximum benefit from these developments (Libertun de Duren, 2007). One of our interviewees described what he saw as

the absence of the state as planner and regulator because what was not present in Pilar was the making of the city. So anyone came and put up barbed wire and built something (Consultant, CBRE, 20 April 2009). ${ }^{17}$

For some observers, gated communities have brought significant benefits to the local population in Pilar

doubtless, the big [gated community] developments ... have brought a lot of improvements and people who chose to live here now find that there are many services and infrastructure, like sewage, gas, Internet, that the original residents of Pilar did not have. Each new development has several advantages because they are modern projects (manager, Fundación por Pilar, 15 April 2009). ${ }^{18}$

However, this can be contested since improvements in infrastructure have taken place only in the areas where gated communities are located, which are not the poor areas. For instance, Manuel Alberti, one of the poorest localities in Pilar with 40 per cent of its population in poverty and 20 per cent in extreme poverty, does not have paved streets, nor water, sewage and sanitation supplies.

The suspicion remains that the 'planning gain' from these large developments has been modest. Developers are obliged to give a proportion of their land back to the 
municipality as planning gain, but there has been little control over this process with parcels of land which are some distance from the development being given in return for planning approval; these land parcels are in a poor location or in areas liable to flooding. Thus improvements that have been made are piecemeal and have yet to knit Pilar together in terms of infrastructure like roads, water supply and service provision, and may ostensibly be to serve the gated communities themselves in the form of access roads and the like. Indeed, only 13 per cent of the roads of Pilar are paved (CIPPEC, 2005).

The 'flexibility' of the planning system in Pilar, along with the underresourced nature of the local government, was also an important factor

That made it easier for investments to come here. But that created some problems because there are about 70 per cent of these developments which are located on flooded lands. The investor takes advantage of the cheap land and does some hydraulic works to comply with the law and then sells it, even if not all legal issues are clear. Today we have environmental problems ... They can be sorted out, but you have to control them. And the government doesn't have the capacity in terms of number of people and skilled people to do this (director of planning, Municipality of Pilar, 7 April 2009).

The growth of 'closed' communities in the form of gated residential developments also exists alongside a significant and persistent burden of unmet basic needs that falls upon the municipal government of the 'open' city. As a local political representative describes it

We, as a municipality, need to solve the needs of people who came to Pilar looking for a job and unfortunately didn't get it. Or people who lived here before the growth of Pilar and already had problems of getting in the job market because they don't have training or skills ... Unfortunately, I see that some times we are running behind events: gated communities came, people from different social groups settled here, and we were not ready for a fast response to people's needs (councillor, Municipality of Pilar, 17 April 2009).

Here, it is interesting to note that the relatively modest elements of planning gain 'won' from developers along with any wider sense of social responsibility felt by developers and residents of gated communities have been focused on some of these poorer communities, mainly in the form of charity activities and some tarmac for the unpaved roads. However, planning gain has not always been won and the process of winning it has not always been transparent, as an interviewee explained

This is not institutionalised ... If something has a negative externality, the government can ask for compensation for the surrounding area. But this was not used in a clear or transparent way. It was more like: 'you have to pay me'. Now this is done in a transparent way and is translated into paved streets because we have a big deficiency here: only 20 per cent of the road infrastructure is paved. This is working very well now (director of planning Municipality of Pilar, 7 April 2009).

The contribution of gated communities in Pilar to resolving these accumulated burdens is mediated through the work of civic bodies and charities. Thus a local priest recalled how

There were no schools in the area 20 years ago, neither health emergency surgeries nor parishes. Now the local church runs several centres for the assistance of the population ... these educational and social works are developed with the help of gated community residents. The development of gated communities has created job opportunities for local people to have more decent lives (Priest, Manuel Alberti district, 12 May 2009). ${ }^{19}$

The Fundación por Pilar emerged in part as recognition of the apparent socioeconomic 
divides that exist in the municipality. The Fundación was created in 2000 and originally had broader aspirations in communitybuilding in conjunction with the municipality. This vision for Pilar promoted through the Fundación por Pilar with its strong links to the development community was a very different one from that centred on historical Pilar. In Thuillier's words

Insisting on the connection between gated communities and economic dynamism, the foundation does not hesitate to foresee for the area's future 'Pilar Valley', a kind of Argentinian edge city, a subtle blend of high-tech corporations, gated housing developments and golf greens (Thuillier, 2005, p. 269).

More recently, the Fundación has retreated somewhat from such broad visions for community-building to Pilar, to a more pragmatic narrowing of its aims to develop poverty reduction schemes in relation to access to health services and educational development.

\section{Social Cohesion in Pilar: Gated Communities and the Dual Suburb}

The phenomenal population growth in Pilarin which gated communities have been the key dynamic directly and indirectly-has also thrown up some new and significant societal divisions which in turn are suggestive of how the impact of gated communities on society might be judged. As one interviewee summarised

The city of Pilar has one of the most polarised social and urban structures. The impact of the development of gated communities and a process of economic growth based on services created a segregated urban fabric and polarised social structure and also the worsening of the historical urban centre (Secretary of Municipalities, National Government, 8 April 2009).
The types of society, economy and polity emerging in Pilar as a result of this new round of investment raise important questions regarding the contribution that gated communities make, not least because

Actually defining who the deserving members of the local polity are determines the perceptions of the benefits gated communities provide (Libertun de Duren, 2007, p. 622; original emphasis).

The job opportunities generated by gated communities meant that people from other areas moved to Pilar and therefore informality and poverty grew alongside the expansion of gated communities, even when they were not as visible as the latter

Unfortunately, Pilar has two Pilars and this is really noticeable. There is a blossoming place where you can live very comfortably and then there is another Pilar which is the 8th poorest localities of the province (manager, Fundación por Pilar, 15 April 2009).

In actual fact, the picture is a little more complicated than this suggests. There are some potentially curious divisions and coexistences developing in Pilar. Residents are now informally divided into NyCs (nacidos $y$ criados-born and bred) and venidos $y$ quedados (came and stayed) or Non-NyCs. Furthermore, it seems-although it is not recognised - that there are two types of NonNyCs: the 'visible' ones, who have moved to Pilar to live in gated communities, and the 'invisible' ones, who have moved to Pilar to find job opportunities either in the industrial park or in the gated communities.

This last group consists of many people with unmet basic needs, which has turned Pilar into a poor district with high infant mortality $\left(19 \%_{0}\right)$, illiteracy (2 per cent) and school drop-out (93 per cent of children of school age attend primary school and only 50 per cent attend secondary school) and 
lack of basic services. Twenty-five per cent of the population of Pilar had unmet basic needs in 2001 (CIPPEC, 2005). In the same year, 84 per cent of total households living in Pilar did not have sewerage; 76 per cent did not have a water supply; 60 per cent did not have a gas supply; 7 per cent did not have electricity; 24 per cent lived in a neighbourhood with no street lighting and no paved streets (45 per cent) or public transport infrastructure (27 per cent) (Vidal-Koppmann, 2007). The relative numbers of households living with unmet basic needs in Pilar decreased from 1991 to 2001, but in absolute numbers this group grew from 7800 to 12100 in that period (CIPPEC, 2005). According to census data, between 25 per cent and 44 per cent (according to the locality) of the population of Pilar were unemployed in 2001 (CIPPEC, 2005). Moreover, in this picture, the original NyCs population now appear somewhat marginalised. As one interviewee said

There are two groups: the poor surrounding neighbourhoods, who ... just want to be treated well and they can survive-it is not much what they ask for!- and the pueblo, which are the NyCs, which is a group that is becoming smaller and smaller, and in many cases they have opposed the growth of Pilar (president, national construction company, main developer of gated communities in Pilar, 20 April 2009).

These social divisions now also appear to coalesce around two distinct city visions that orient themselves to two distinct centres within the municipality. There remains the historical centre represented by the public Pilar Square which is used by NyCs and poor (and 'invisible') Non-NyCs, but only very occasionally by affluent (and 'visible') Non-NyCs when they need to do legal or bureaucratic activities, or go to the municipality. The second centre is the car-oriented shopping and entertainment complex of Kilómetro 50, used by Non-NyCs who live in gated communities. Here then, "for the newer residents, the traditional centre of Pilar doesn't exist. It is now for other social groups" (developer of a mega project in Pilar, 15 April 2009), while some middle-class NyCs also use this second centre: "We used to go for a stroll to the square, now we go to the shopping centres" (representative, Chamber of Commerce, Pilar, 17 April 2009).

Discussing the contribution of gated communities and the industrial park to the 'open city', one representative from the municipal government of Pilar described how

The centre of Pilar hasn't improved and everybody wants to go to Kilómetro 50. Some commercial infrastructure is better. There are many restaurants now. But there are other areas where there is no improvement. There is a sort of competition between the two centres. If you go to Kilómetro 50 on a Saturday night, it is crowded, while the centre of Pilar is completely deserted. People who live in the centre also go to Kilómetro 50 (director of planning, Municipality of Pilar, 7 April 2009).

Moreover, the amenity value of an outer suburban area favoured for its environment is largely appropriated within closed communities rather than the open city. Public spaces in Pilar are poorly provided for and are often in poor condition. Although the municipality has plenty of green areas -about 60 per cent of the territory-they are mainly privately owned and less than 10 per cent is public (director of planning, Municipality of Pilar, 7 April 2009).

It is difficult to demonstrate directly the connections between the various new elements of Pilar - the accelerated growth of gated communities, the accretion of a shopping area and office development, hotels, educational amenities and industrial park. They contribute to the fragmented nature of Pilar's urban fabric and this no doubt is due at least in part to the car-dependent nature of these developments. Some further sense of this is suggested by the way in which increased social 
distance and differentiation have become part of everyday life in Pilar-relationships between gated community residents and residents of the 'open city' are seen to be

in a bad way. It is the poor and the rich guys. It is a sort of exclusion. There are more security guards in gated communities than the police staff in Pilar (director of planning, Municipality of Pilar, 7 April 2009).

\section{Conclusion}

The development of gated communities in cities all over the world has lately received considerable scholarly attention. Although this phenomenon presents similarities related to a 'globalised' lifestyle and a global trend encouraged by developers, it also has important features that are context specific. These include issues of the wider economic, political and social impacts of gated communities which typically have been less the subject of study than their specific characteristics and the residential preferences associated with them. In the course of this paper, we have examined the contribution of one group of private-sector interests (gated communities) in the urbanisation of suburbia in the Latin American setting, and particularly in the improvement of the urban condition of the suburban municipality outside these gated communities. For some, the rise of these gated communities in peripheral areas where they were largely absent before is not a break from past patterns of urbanisation in the Latin American city, but rather a consequence of on-going "social polarisation, ubiquitous urbanisation and loss of primacy of traditional urban cores" (Libertun de Duren, 2007, p. 623). This is a highly schematic view of recent history of the periphery of Latin American cities and our research suggests that important discontinuities may indeed be apparent. However, this is not to say that developments at the edges of metropolitan areas in Latin America are converging on the sorts of patterns that have been celebrated in the US setting.

If the case of Pilar can be considered to give an insight into the contribution of gated communities to the urbanisation of suburbia, then their impact seems likely to crystallise not soften social inequalities, segregation and spatial fragmentation at the municipal scale. Whilst there is evidence of the contribution that gated communities have made to piecemeal improvements in the suburban economy signalled in additional amenities, services and infrastructure, these do not appear to have amounted to a rounding-out and knitting together of communities at the municipal level. Instead, these developments appear to reflect and reinforce something of a dualistic process of suburbanisation. Poverty and exclusion have increased at the same time as wealth and social distinction. 'Planning gain' has proved an inadequate tool with which significantly to improve conditions in the municipality so that stark differences exist between the 'private' cities of gated communities and the rest of Pilar. Gated communities have made their contribution to the activities of religious and civic bodies concerned with poverty alleviation; however, social polarisation continues to increase not least due to a bifurcation in the social structure of Pilar. Yet again the Pilar case is interesting in highlighting the need to examine carefully the changing dynamics within classes in the metropolitan periphery in light of some unusual cross-class alignments and to think about urban policies that could contribute to diminish these differences in the urban landscape rather than making them more visible.

This paper contributes to understanding gated communities in the broader context of their contribution to the urbanisation of suburbia. They could be seen as one of the elements of contemporary (post-)suburbanisation. In this sense, it is important to consider how they relate to other elements that also now increasingly characterise suburbia, like 
entertainment, shopping and education facilities. Finally, it is also important to consider to what extent and how local governments are able to cope with the pace of such developments and are able to knit them together into something that might resemble viable and sustainable post-suburban communities.

\section{Notes}

1. Interviews were conducted in Spanish and translated by the authors.

2. The term 'élite' refers here to actors in a 'position of power', mainly policy-makers, developers and real estate agents who are involved in the development of gated communities. The concept has been largely discussed in relation to 'élite interviewing' and specifically to the notion of 'power' (see for instance, Smith, 2006). Interviewees were identified based on the literature on Pilar and previous research on Pilar by other authors, and also during the research fieldwork: some interviewees were either suggested by other interviewees or mentioned during the interviews. The purposive sampling included actors from different sectors and occupying different roles (i.e. private and public sectors, national and local governmental tiers).

3. As explained later in the text, Tortugas Country Club is the first gated community of Argentina, created in 1930. For more information, visit its website www. tortugascountryclub.com.ar.

4. For the purposes of simplifying the objectives of this paper, we consider here 'private city' as synonymous with 'closed city' that refers to privatised spaces, like gated communities and shopping centres, and 'public city' as synonymous with 'open city', referring to non-gated developments and public urban spaces. This binary distinction is, as we make clear in our discussion, not always a very satisfactory one.

5. For a literature review on the development of gated communities, see Roitman (2010) and Roitman and Giglio (2010) for references on the main arguments on the topic.

6. It is at this point that international trade theory alerts us to the effects of gated communities being analogous to those of trade and investment 'diversion', whereby there is the potential for expensive and inefficient provision of services substituting for those that would otherwise be provided by municipal government.

7. Although Pírez refers here to the case of Buenos Aires and Argentina, this can be also applied to other national contexts.

8. For an analysis of the literature on gated communities and social segregation, see Roitman (2008).

9. Molotch (1976) describes how city politics in the US is driven by landed business interests who stand to gain by the uplift in the value of land and property, notably when raw or derelict land is allocated for residential, commercial or industrial development realised through exchange (purchase and sale of land and property). Phelps and Wood (2011) argue that this interest in the increased exchange values produced through the development process may actually apply most accurately to suburban rather than urban development. In cities, existing, accumulated patterns of development, land use and lease create an on-going interest in the use value of land and property.

10. This is the current area of Pilar. In 1994, the provincial law 11.551 (20 October 1994) modified the administrative borders of some municipalities of Buenos Aires Province and created Municipalidad de Malvinas Argentinas. Malvinas Argentinas annexed land that was formerly part of Pilar and the Municipality of General Sarmiento (VidalKoppmann, 2007).

11. There are seven types of gated communities in Argentina; 'country clubs', 'closed neighbourhoods'-barrios cerrados or privados; 'marinas', 'farm clubs', 'gardentowers'-torres-jardin; 'mega projects' and 'condominiums'. For a description of these types, see Roitman (2008, pp. 25-30).

12. Panamericana, officially called Northern Access, was formerly a National Route built in the 1970s.

13. Although this type uses the word 'condominium', this is different from 'condominium' as the legal form in which 
land is used in some gated communities. Many gated communities in Argentina used the legal figure of condominium for the land property status, even if they are not called 'condominium'.

14. Some interviewees referred to a 'collapse' of Panamerica due to the large number of people who commute to Capital Federal everyday which has congested the motorway and extended commuting time considerably at peak hours.

15. Nacidos y criados-born and bred-refers to the group of residents who were original residents of Pilar before the development of gated communities or the creation of the industrial park. They are distinct from those called 'venidos y quedados'-arrived and stayed-(also known as Non-NyCs), who are mainly the new residents of Pilar who live in gated communities. This last category does not include the new residents who live in informal settlements. To make this differentiation, we call them 'visible NonNyCs' and 'invisible Non-NyCs' respectively because the latter are not considered in the everyday discussion as part of the new population of Pilar, since the municipality is usually only recognised as wealthy.

16. San Isidro is an upper-class residential district in the north of Buenos Aires (first ring) and Tigre is a municipality located also in the north, which is now competing with Pilar in terms of gated community developments.

17. More charitably, this reflects the extreme commercial pressure that developers feel they face to exploit opportunities at relevant points in what has been a very unstable national economic cycle (developer of a mega-project in Pilar), which in turn has combined with the expedient planning approach of the past. There is something of an irony here since wealthy sections of society in Argentina have benefited from an informal market (Secretary of Municipalities, National Government) so that the municipality's attempt to tighten its planning approach coupled with an increasingly outdated local plan (not revised since 1985) have actually created uncertainty in the minds of developers, with the development of gated communities tailing off in recent years (real estate agent; and developer, Estancias del Pilar).

18. Fundación por Pilar is an NGO that works mainly on health and education projects carried out in the poorest neighbourhoods of Pilar. It is privately funded by local families and companies and runs annual fundraising events.

19. E-mail communication.

\section{Acknowledgements}

We are grateful for funding provided for this research by the UCL-Abbey Research Collaboration Fund 2008. We would also like to thank Gabriel Fernández and Germán Leva at Quilmes University (Argentina) and Cynthia Goytia at Di Tella University (Argentina) for their assistance and hospitality during fieldwork and last but not least all our interviewees for their time and collaboration.

\section{References}

Barsky, A. and Vio, M. (2007) La problemática del ordenamiento territorial en cinturones verdes periurbanos sometidos a procesos de valorización inmobiliaria: el caso del Partido del Pilar, Región Metropolitana de Buenos Aires. Paper presented at the IX Coloquio Internacional de Geocrítica: 'Los problemas del mundo actual. Soluciones y alternativas desde la geografía y las ciencias sociales', Porto Alegre, Universidad Federal do Rio Grande do Soul, May/June.

Blakely, E. J. and Snyder, M. G. (1997) Fortress America: Gated Communities in the United States. Washington, DC: Brookings Institution Press.

Borsdorf, A. and Hidalgo, R. (2008) Der Urban Sprawl in Europa und Lateinamerika: Ein Vergleich der Entwicklungen europäischer und lateinamerikanischer Agglomerationen, Mitteilungen der Österreichischen Geographischen Gesellschaft, 150, pp. 229-250.

Borsdorf, A., Hidalgo, R. and Sánchez, R. (2007) A new model of urban development in Latin America: the gated communities and fenced cities in the metropolitan areas of Santiago de Chile and Valparaiso, Cities, 24, pp. 365-378.

Caldeira, T. (2000) City of Walls: Crime, Segregation and Citizenship in Sao Paulo. Berkeley, CA: University of California Press. 
Ciccolella, P. and Vecslir, L. (2010) Nuevos espacios del terciario y transformación metropolitana en Buenos Aires. Paper presented at the XI Seminario Internacional Red Iberoamericana de Investigadores sobre Globalización y Territorio, Mendoza, Argentina, October.

CIPPEC (Centro de Implementación de Políticas Públicas para la Equidad y el Crecimiento) (2005) Diagnóstico para la Planificación. Caso Municipio de Pilar, October.

Dear, M. and Flusty, S. (1998) Postmodern urbanism, Annals of the Association of American Geographers, 88, pp. 50-72.

Dick, H. and Rimmer, P. (1998) Beyond the Third World city: the new urban geography of southeast Asia, Urban Studies, 35, pp. 2303-2321.

Fishman, R. (1987) Bourgeois Utopias: The Rise and Fall of Suburbia. New York: Basic Books.

Frug, G. (1999) City Making: Building Communities without Walls. Princeton, NJ: Princeton University Press.

Garreau, J. (1991) Edge City: Life on the New Frontier. New York: Doubleday.

Le Goix, R. (2005) Gated communities: sprawl and social segregation in southern California, Housing Studies, 20, pp. 323-343.

Goytia, C. (2005) Private residential investment growth: implications on municipal revenues and socio-economic indicators. the case of the municipality of Pilar. Paper presented at the Urban Research Symposium 2005, World BankIPEA, April.

INDEC (Instituto Nacional de Estadísticas y Censos) (n.d.) INDEC website. Argentina (http://www.indec.gov.ar).

Kirby, A. (2008) The production of private space and its implications for urban social relations, Political Geography, 27, pp. 74-95.

Libertun de Duren, N. R. (2007) Gated communities as a municipal development strategy, Housing Policy Debate, 18, pp. 607-626.

Massey, D. (1994) A global sense of place, in: D. Massey (Ed.) Space Place and Gender, pp. 146-156. Cambridge: Polity.

McKenzie, E. (1994) Privatopia: Homeowner Associations and the Rise of Residential Private Government. New Haven, CT: Yale University Press.

Molotch, H. (1976) The city as a growth machine: toward a political economy of place, American Journal of Sociology, 82, pp. 309-332.
Phelps, N. A. and Wood, A. M. (2011) The new post-suburban politics?, Urban Studies (forthcoming).

Phelps, N. A., Parsons, N., Ballas, D. and Dowling, A. (2006) Post-suburban Europe: Planning and Politics at the Margins of Europe's Capital Cities. Basingstoke: Palgrave-Macmillan.

Pírez, P. (2002) Buenos Aires: fragmentation and the privatization of the metropolitan city, Environment \& Urbanization, 14, pp. 145-158.

Publicountry S.R.L. (2005) Guía de Countries, Barrios Privados y Chacras. Publicountry S.R.L., Capital Federal, Argentina.

Roitman, S. (2008) Urban social group segregation: a gated community in Mendoza, Argentina. Unpublished $\mathrm{PhD}$ thesis, Development Planning Unit, University College London.

Roitman, S. (2010) Gated communities: definitions, causes and consequences, Urban Design and Planning, 163(1), pp. 31-38.

Roitman, S. and Giglio, M. A. (2010) Latin American gated communities: the latest symbol of historic social segregation, in: S. Bagaeen and O. Uduku (Eds) Gated Communities: Social Sustainability in Contemporary and Historical Gated Developments, pp. 63-78. London: Earthscan.

Roitman, S., Webster, C. and Landman, K. (2010) Methodological frameworks and interdisciplinary research on gated communities, International Planning Studies, 15(1), pp. 3-23.

Sabatini, F. and Cáceres, G. (2004) Los barrios cerrados y la ruptura del patrón tradicional de segregación en las ciudades latinoamericanas: el caso de Santiago de Chile, in: G. Cáceres and F. Sabatini (Eds) Barrios Cerrados en Santiago de Chile: entre la exclusión y la integración residencial, pp. 9-43. Pontificia Universidad Católica de Chile, Instituto de Geografía and Lincoln Institute of Land Policy, Santiago de Chile.

Sabatini, F. and Salcedo, R. (2005) Gated communities and the poor in Santiago, Chile: functional and symbolic integration in a context of aggressive capitalist colonization of lower class areas. Paper presented at the conference Territory, Control and Enclosure: The Ecology of Urban Fragmentation, Pretoria, February/March.

Smith, K. E. (2006) Problematising power relations in 'elite' interviews, Geoforum, 37, pp. 643-653.

Svampa, M. (2001) Los que ganaron: la vida en los countries y barrios privados. Buenos Aires: Biblos. 
Teaford, J. (1997) Post-suburbia: Government and Politics in the Edge Cities. Baltimore, MD: Johns Hopkins University Press.

Thuillier, G. (2005) Gated communities in the metropolitan area of Buenos Aires, Argentina: a challenge for town planning, Urban Studies, 20, pp. 255-271.

Verdecchia, C. R. (1995) Los clubes de campo, Revista Arquis, 5, pp. 26-28.
Vidal-Koppmann, S. (2007) Transformaciones socio-territoriales de la Región Metropolitana de Buenos Aires en la última década del Siglo XX: la incidencia de las urbanizaciones privadas en la fragmentación de la periferia. Unpublished PhD thesis, FLACSO Argentina.

Webster, B. (2002) Property rights and the public realm: gates, greenbelts, and gemeinschaft, Environment \& Planning B, 29, pp. 397-412. 